\title{
Behavioural Modification Techniques as Tools for Performance Enhancement in the Nigerian Banking Industry: A Survey of Selected Banks in Makurdi
}

\author{
Sev Joseph Teryima, Agburu John Ikwueba, Ahua Samuel \\ Benue State University, Makurdi, Nigeria
}

\begin{abstract}
This paper is a critical analysis of behavioral modification techniques as tools for performance enhancement in the Nigerian Banking Industry. The overriding objective of the study was to determine the impact of behavior modification techniques on performance enhancement in the Nigerian banking industry. The specific focus was on selected banks in the Makurdi metropolis, Benue State. The study employed a simple empirical survey method with a view to eliciting relevant data for analytical purpose so as to answer several questions and to obtain the objectives of the study. Both primary and secondary sources were explored in a bid to attain data which were considered to be highly germaine to the investigation under reference. Five-point Likert scale rating questionnaire was used in obtaining the views and opinions of respondents (i.e. strongly agree -5 , agree - 4 , undecided-3, disagree-2, and strongly disagree-1). Two hypotheses were formulated and tested. Non-parametric tools including simple percentages and Pearson Chi-square statistics were used due to their analytical simplicity and relevance. The study found that banks in Makurdi utilized behavior modification strategies translated to high organizational success or enhancement in a comparative sense. This was evident from the fact that the banks net profitability trends were observed to be upwards generically. In the light of the findings of the study, it is hereby recommended that proactive behavior modifications strategies rules guideline and the like be tailored along lines with greatest organizational profitability trends and performance enhancement profiles, both potential and actual. This will require rewarding productive behaviors that detect/report fraudulent acts with cash gifts, meritawards, prizes and discouraging unproductive behaviors such as fraudulent activities, absenteeism, drug abuse, alcoholic influences and lateness to work amongst others with punishment, extinction, and negative reinforcement.
\end{abstract}

Keywords: behavior, modification, performance, techniques, banking

Sev Joseph Teryima, Ph.D., senior lecturer, Faculty of Management Sciences, Department of Business Management, Benue State University, P.M.B 102119, Makurdi, Nigeria, West Africa.

Agburu John Ikwueba, Ph.D., associate professor, Faculty of Management Sciences, Department of Business Management, Benue State University, P.M.B 102119, Makurdi, Nigeria, West Africa.

Ahua, Samuel, B.Sc., MBA., Faculty of Management Sciences, Department of Business Management, Benue State University, P.M.B 102119, Makurdi, Nigeria, West Africa.

Correspondence concerning this article should be addressed to Sev Joseph Teryima, Faculty of Management Sciences, Department of Business Management, Benue State University, P.M.B 102119, Makurdi, Nigeria, West Africa. E-mail: Josephteryima@gmail.com. 


\section{Introduction}

\section{Background}

Understanding why people do the things they do on the job is not an easy task for managers, predicting their response to management's latest program is yet a harder responsibility. As noted by Griffin (1997) individual differences are personal attributes that vary from one person to another. Individual differences may be physical, psychological, and emotional. Taken together, all of individual differences that characterize any specific person serve to make the individual unique from everyone else.

According to Bateman and Snell (1999), Stoner, Freeman, and Gilbert (2000), there exists a psychological contract between the employee and the employer (organization). The psychological contract is the overall set of expectations held by an individual with respect to what he or she will contribute to the organization and what the organization will provide to the individual. Psychological contract is not written on paper, nor all of its terms explicitly negotiated.

According to Griffin (1997), contributions from the individual employees come in the form of efforts, ability, loyalty, skills, time, and competencies while inducements from the organizations are in the form of pay, job security, benefits, career opportunities, status, and promotional opportunities. A basic challenge faced by the organization, then, is to manage psychological contracts. The organization must ensure that it is getting value from its employees. At the same time; it must also be sure that it is providing employees with appropriate inducements. If the organization is underpaying its employees for their contributions for example, they may perform poorly or leave for better jobs elsewhere. Such employees may exhibit work place behavior that will be dissatisfied, divergent from the norms of the organizations.

According to Luthans (2002) workplace behavior is a pattern of action by the members of an organization that directly or indirectly influence organizational effectiveness. These workplace behaviors range from performance, absenteeism and turnover and organizational citizenship. Griffin (1997) opined that performance behaviors are the total set of work-related behaviors that the organization expects the individual to display. Thus, they derive from the psychological contract. For some jobs, performance behaviors can be narrowly defined and easily measured, for example, an assembly line worker who sits by a moving conveyor and attached parts to a product as it passes by has relatively few performance behaviors. He or she is expected to remain at the workstation and correctly attached the parts. Other important types of work-related behaviors are that result in withdrawal - absenteeism and turnover.

Absenteeism occurs when an individual does not show up for work. The cause may be legitimate (illness, death in the family, etc.) or feigned reported as legitimate but actually just an excuse to stay home. When an employee is absent, her or his work is left undone unless a substitute must be hired to do it. In either case the quantity and quality of actual output are likely to suffer. Obviously, some absenteeism is expected. The important concern of organizations is to minimize feigned absenteeism and reduce legitimate absences as much as possible as well, such as job dissatisfaction and low morale.

Turnover occurs when people quitted their jobs. An organization usually incurs costs in replacing individuals who have quit, but if turnover involves especially productive people, it is even more costly. Turnover seems to result from a number of factors including aspects of the job, the organization, the individual, the labor market, and the family influences. In general, person-job-fit is also likely the cause of turnover. 
Organizational citizenship refers to the behavior of individuals that makes a positive overall contribution to the organization, the example here is an employee who does work that is acceptable in terms of both quantity and quality. Organization itself, especially its culture, must be able to promote, recognize, and reward these types of behaviors if they are to be maintained, hence these will enhance organizational effectiveness and positive performance.

This paper attempts to $\mathrm{x}$-rayed the various techniques that can be adopted in modifying workplace behavior of organization in order to attain positive performance in the organization.

\section{Statement of the Problem}

There have been several attempts by the executive management of banking firms in Nigeria to contemplate eliminating undesirable behaviors and upholding desired work place behaviors. Banking firms over sometime now have adopted behavior modification strategies in the range of positive reinforcement, negative reinforcement, punishment, and extinction in a bid to facilitate sound work place behaviors. More to that, sound reforms, prudential guidelines and ethical compliance, and supervisory department have been established to curb counterproductive behaviors such as financial frauds, absenteeism, sabotage, drug abuse among others. Notwithstanding, there exist trends of poor performance, low profit turnovers, low market share, and distress amongst banking firms in Nigeria. The researchers therefore wish to establish why despite the behavior modification techniques/strategies, there is still declining performance in the banking industry.

\section{Research Questions}

(1)To what extent have the Nigerian banking firms enhanced quality performance with the application of behavior modification techniques/strategies?

(2)To what extent have the Nigerian banking firms recorded upward improvement in profit attainment with the application of behavior modification techniques/strategies?

\section{Research Objectives:}

(1)To examine the impact the application of behavior modification techniques/strategies has on enhancing quality performance in the Nigerian banking firms.

(2)To evaluate the extent to which the application of behavior modification techniques/strategies has recorded upward improvements in profit status and attainment in the Nigerian banking firms.

\section{Research Hypotheses}

$\mathrm{H}_{1}$ : The effective application of behavior modification techniques/strategies has not significantly impacted the performance of the banking firms in Nigeria.

$\mathrm{H}_{2}$ : Behavior modification techniques have not enhanced the attainment of high profit status in the banking firms in Nigeria.

\section{Literature Review}

\section{Concept of Behavior Modification}

Behaviorism has led to the development of techniques of behavior modification. These were first used for the treatment of mental disorders, learning disorders, phobias, for psychiatric rehabilitation, and for accidents and trauma recovery. The applications have been extended to organizational setting since then.

According to Buchanan and Huczynski (2004) and Yalokwu (2006), behavior modification is a technique for encouraging desired behaviors and discouraging unwanted behaviors using operant conditioning 
(consequence). The consequences of a given behavior could determine whether the same behavior is likely to occur in the future or not. Based upon this direct relationship between, behavior and its consequence, management can study and analyze the relationship and try to modify and control behavior by manipulating consequences. It is a reinforcement process by which certain types of behaviors are strengthened. In this understanding a "reinforcer" is a stimulus that causes certain behavior to be repeated or inhibited. Organizations are interested in reinforcing desirable behavior and eliminating undesirable ones among workers (Dyck \& Neubert, 2009). By introducing some reinforcers, they can maintain or increase the probability of such behaviors as quality-oriented performance, objective decision making, high level of attendance and punctuality. Thus, these reinforcers work as behavior modifiers.

According to Schermerhorn, Hunt and Osborn (2005), Mcshane and Glinow (2004), Luthans (2002) there are four reinforcement strategies/behavior modification techniques and options adopted by organizations, which include: positive reinforcement, negative reinforcement, punishment, and extinction. But before any of these techniques/options or strategy will be adopted in any organizational setting, Luthans and Kreitner (1985), F. Luthans, Stajkovic, B. C. Luthans, and K. W. Luthans (1988), and Buchanan and Huczynski (2004) developed five main steps to be followed in any behavior modification exercise in organization. These include:

(1) identifying the critical, observable and measurable work performance related behaviors to be encouraged;

(2) measuring the current frequency of those behaviors to provide a baseline against which to measure improvement;

(3) establishing the triggers or antecedents for those behaviors and also establishing the consequences - positive, neutral, and negative that follows from those behaviors;

(4) developing an intervention strategy to strengthen desirable behaviors and weaken dysfunctional behaviors through the use of positive reinforcement (money, recognition) and corrective feedback, noting that punishment may be necessary in some instances, for example, to inhibit unsafe behaviors;

(5) evaluating systematically the effectiveness of the approach in changing behavior and improving performance compared with the general baseline measurement.

Behavior modification can appear particularly attractive to managers who are often in ideal positions from which to manipulate the reinforcement of certain employee behaviors. Managers also tend to find this approach attractive because it argues that what has to be changed is behavior and that to achieve this one needs to know very little about the complex internal workings of the people concerned.

Examples of desirable workplace behaviors could include, for example, speaking courteously to customers, attending training to develop new skills, and being helpful to colleagues. Undesirable behaviors could include lateness, the production of poor quality items, and being rude to customers, fraudulent companies' acts.

Behavior modification uses the principle of reinforcement to eliminate undesirable behavior and to increase the frequency of desired work behavior.

The typical features of organizational applications of organizational behavior modification are:

(1) It applies to clearly identifiable and observable behavior, such as time keeping, carrying out checks and repairs, and the use of apartmental work methods;

(2) Rewards are contingent on the performance of the desirable behavior;

(3) Positive reinforcement can take a number of forms, from the praise of a superior to cash prizes, to food, and to clothing; 
(4) The desired modification in behavior may only be sustained if positive reinforcement is continued (although this may be intermittent).

The reinforcement strategies and techniques organizations adopt in modifying behavior are summarized below and the first two reinforcers seek to discourage undesirable behavior, which are as following.

(1) Positive reinforcement: A positive reinforcement is a reward for a desired behavior. The reward should be sufficiently powerful and durable so that it increases the probability of the desirable behavior. Financial incentive is probably the most powerful reinforce for positive behavior because money can be used for getting all kinds of other resources. Non-monetary positive reinforcers could be participative in decision making, recognition for a job well done, challenging tasks, higher responsibility, freedom to decide how the job is to be done, and the like.

Since all individuals have different motivations for performance, it is important that positive reinforcement be individually tailored so that the given reinforce is valued by the employees.

(2) Negative reinforcement: This is the removal of an unpleasant consequence following a desired behavior. Employee changes their behavior to avoid unpleasant consequences such as criticisms or a poor evaluation. It is known as "avoidance learning", which involves learning how to avoid unpleasant consequences, for example, a manager may like his subordinates to dress in complete business suites when they come to work and may criticize individuals who dress casually, however, this criticism stops when such individuals wear business suits to work, and thus to avoid criticism, the employees may dress well; similarly, students work hard, write term papers, and do their homework on time to avoid the consequences of failure in the exams.

(3) Punishment: This is the administration of negative consequences following an undesirable behavior. The purpose is to decrease the odds of the undesirable behavior being repeated.

According to Skinner (1981), punishment is still the most common techniques of behavior control. When children misbehave, they are spanked; if workers do not behave according to the way their organization want, they are ridiculed or reprimanded going so far as having them arrested and failed.

Religions threaten punishment in the life hereafter, if a person does not behave according to God's will and Doctrine Guidelines.

However, Walters and Grusek (1977) from a review of research suggested that punishment can be effective if it meets the following conditions:

- The punishment should be quick and short;

- It should be administered immediately after the undesirable behavior;

- It should be limited in its intensity;

- It should be specifically related to behavior and not to character traits;

- It should be restricted to the context in which the undesirable behavior occurs;

- It should not send "mixed message" about what is acceptable behavior;

- Penalties should take the form of withdrawal of rewards, not physical pain.

(4) Extinction: This is the withdrawal of a positive reward and removal of all reinforcements following an undesirable behavior, for example, if a student in a class is highly mischievous and disturbs the class, he or she is probably asked for attention. If this attention is given, the student will continue to exhibit that behavior. However, if he or she continuously ignored and did not mind, then such undesirable behavior will vanish over a period of time. 
To such a student, attention is a positive reinforcement and when this reinforcement is withheld from him or her, the disturbing behavior is expected to decrease in frequency and eventually disappear. At this juncture it may be advisable to examine some specific behavior modification strategies. This is the focus of the next segment.

\section{Hammers Rules for Using Behavior Modification Strategies/Techniques}

Hammer (1977) has developed a six-rule formula for using behavior modification, which are:

Rule 1: Don't reward all individuals equally. To be effective behavior reinforceers, rewards should be based on performance. Rewarding everyone equally in effect reinforces poor or average performance;

Rule 2: Be aware that failures to respond can also modify behavior. Managers influence their subordinates by what they don't do as well as by what they do, for example, failing to praise a deserved subordinate may cause that subordinate to perform poorly the next time;

Rule 3: Be sure to tell individuals what they can do to get reinforcement. Setting a performance standard lets individuals know what they should do to be rewarded; they can then adjust their work pattern accordingly;

Rule 4: Be sure to tell individuals what they are doing is wrong. If a manager withholds rewards from a subordinate without indicating why the subordinate is not being rewarded, the subordinate may be confused about what behavior the manager finds undesirable. The subordinate may also feel that he or she is being manipulated;

Rule 5: Don't punish in front of others. Reprimanding a subordinate might sometimes be a useful way of eliminating an undesirable behavior. Public reprimand, however, humiliates the subordinates and this causes all the members of the work group to resent the manager;

Rule 6: Be fair. The consequence of a behavior should be appropriate. Subordinates should be given the rewards they deserve. Failure to reward subordinates properly or over-rewarding undeserving subordinates reduces the reinforcing efforts of rewards.

\section{Reinforcement Theory of Motivation}

The reinforcement theory of motivation shifts the emphasis from employee's underlying needs and thinking processes to attention on the relationship between behaviors and consequences. The theory rests on two premises:

(1) The environment is an important catalyst in determining or reinforcing behavior: If the environment is complementary to established behavior, then such behavior is positively reinforced; if the environment is hostile to the values and skills of the worker, then negative reaction takes place;

(2) Human behavior is subject to the "cause and effect" phenomenon so that effect can be predicted on the basis of established causes and behavior can be changed.

\section{Methodology and Data Analysis}

\section{Research Methodology}

The research design employed in this investigation was largely a quasi-experimental one in the sense that it placed the premium on simple survey. The population of the study consisted of the 485 employees of five banking firms surveyed at the branch level in the Makurdi metropolis, the state capital of Benue State. These banks are shown in Table 1. 
Table 1

Selected Surveyed Banks in Makurdi

\begin{tabular}{llc}
\hline S/No & Name of banking organization & Population size \\
\hline$(1)$ & Zenith Bank plc, Makurdi Branch & 89 \\
$(2)$ & United Bank for Africa (UBA) Makurdi Branches & 117 \\
$(3)$ & Fidelity Bank plc, Makurdi Branches & 71 \\
$(4)$ & First Bank plc, Makurdi Branches & 128 \\
$(5)$ & Diamond Bank plc, Makurdi Branches & 78 \\
& Total employee population & 483 \\
\hline
\end{tabular}

Source: Field survey in 2014.

In determining the sample size, the researcher employed the Yamane's formula (1964). The formula is as follows:

$$
n=\frac{N}{1+N \times(e)^{2}}
$$

where, $n=$ the number of respondents drawn from the target population;

$N=$ target population or universe;

$e=$ the significance level which the researcher have on the sample subject drawn.

In this research, the level of confidence is $93 \%$, hence the significance level is $1-93 \%=0.07$

Applying the Yamane formula above, you can have:

$$
\lambda=\frac{483}{1+483 \times(0.0049)} \approx 143.463
$$

The researchers were able to successfully administer the research questionnaires to all these respondents. Most interestingly and rewardingly too, all the questionnaires served were neatly returned. The analysis that follows here after was based essentially on these returns.

\section{Data Presentation and Analysis}

As data is shown in Table 2 below, behavior modification is a reinforcement strategy for encouraging desirable workplace behaviors and discouraging unwanted workplace behaviors.

Sixty-five respondents representing $45.45 \%$ strongly agreed to the notion while 50 respondents of the survey banking firms standing for $34.97 \%$ agreed. Six respondents representing $4.20 \%$ were undecided on this position. Ten respondents standing for $6.99 \%$ disagreed while 12 respondents representing $8.39 \%$ strongly disagreed on this position.

For most respondents of the banking organizations, behavior modification techniques namely positive reinforcement, negative reinforcement, punishment, and extinction are strongly adopted for modifying employees' behavior.

Information indicated as per data in Table 3 below implies that 48 respondents (34\%) strongly agreed while 60 respondents representing $42 \%$ agreed to the position. Sixteen respondents standing for $11 \%$ disagreed to the view while 19 respondents strongly disagreed representing $13 \%$ of the employees surveyed. No respondent opted for the undecided option. 
Table 2

Respondents View Pertaining to the Assertion That Behavior Modification Is a Reinforcement Process for Encouraging Desirable Workplace Behavior and Discouraging Unwanted Workplace Behaviors

\begin{tabular}{lcc}
\hline Banking Organization & & \\
\hline Response Option & No of Respondents & \% of Respondents \\
\hline Strongly Agree & 65 & $45.45 \%$ \\
Agree & 50 & $34.97 \%$ \\
Undecided & 6 & $4.20 \%$ \\
Disagree & 10 & $6.99 \%$ \\
Strongly Disagree & 12 & $8.39 \%$ \\
Total & 143 & $100 \%$ \\
\hline
\end{tabular}

Source: Field survey in 2014.

Table 3

The Banking Organizations Adopt Behavior Modification Techniques Such as Positive Reinforcement, Negative Reinforcement, Punishment and Extinction

\begin{tabular}{lcc}
\hline Banking Organization & & \\
\hline Response Option & No of Respondents & \% of Respondents \\
\hline Strongly Agree & 48 & 34 \\
Agree & 60 & 42 \\
Undecided & - & - \\
Disagree & 16 & 11 \\
Strongly Disagree & 19 & 13 \\
Total & 143 & 100 \\
\hline
\end{tabular}

Source: Field survey in 2014.

Table 4

Respondents View on the Claim That Behavior Modification Techniques by the Banking Firms Have Enhanced Performance in a Desired Manner

\begin{tabular}{lcc}
\hline Response Option & No of Respondents & \% of Respondents \\
\hline Strongly Agree & 60 & $41.96 \%$ \\
Agree & 57 & $39.86 \%$ \\
Undecided & - & - \\
Disagree & 12 & $8.39 \%$ \\
Strongly Disagree & 14 & $9.79 \%$ \\
Total & 143 & $100 \%$ \\
\hline
\end{tabular}

Source: Field survey in 2014.

In deciding whether behavior modification techniques/strategies have enhanced performance in the survey on banking firms in a desired manner (see Table 4), 60 respondents representing 41.96\% strongly agreed while 57 respondents standing for $39.86 \%$ agreed. No respondents opted for undecided. Twelve respondents (8.39\%) disagreed while 14 respondents representing $9.79 \%$ strongly disagreed on this position.

In considering whether behavior in organizations can be modified only when managers identify the critical, observable and measurable workplace performance related to behaviors to be encouraged and discouraged (see 
Table 5), 45 respondents standing for $31.47 \%$ strongly agreed while 55 respondents standing for $38.47 \%$ agreed on the position. Ten respondents standing for $6.99 \%$ were undecided. Ten representing $6.99 \%$ disagreed while 23 respondents representing $16.08 \%$ strongly disagreed on these subject matters.

Table 5

Respondent Opinion on the Claim That Behavior in Organizations Can Be Modified Only When Managers Identify the Critical Observable and Measurable Work Performance Related Behavior to Be Encouraged and Discouraged

\begin{tabular}{lcc}
\hline Response Option & No of Respondents & $\%$ of Respondents \\
\hline Strongly Agree & 45 & $31.47 \%$ \\
Agree & 55 & $38.47 \%$ \\
Undecided & 10 & $6.99 \%$ \\
Disagree & 10 & $6.99 \%$ \\
Strongly Disagree & 23 & $16.08 \%$ \\
Total & 143 & 100 \\
\hline
\end{tabular}

Source: Field survey in 2014.

Table 6

Respondents' Opinion on Whether High Profits Status is Attained With the Application of Behavior Modification Strategies

\begin{tabular}{lcc}
\hline Response Option & No of Respondents & \% of Respondents \\
\hline Strongly Agree & 49 & $34.27 \%$ \\
Agree & 51 & $35.66 \%$ \\
Undecided & 12 & $8.39 \%$ \\
Disagree & 17 & $11.89 \%$ \\
Strongly Disagree & 14 & $9.79 \%$ \\
Total & 143 & 100 \\
\hline
\end{tabular}

Source: Field survey in 2014.

In deciding as to whether high profit status is attained with the application of behavior modification techniques/strategies such as positive reinforcement, negative reinforcement, punishment and extinction by the banking firms in Nigeria, Table 6 above revealed that 49 respondents consisting 34.27\% strongly agreed to the position while 51 respondents representing $35.66 \%$ agreed on the subject matter; 12 respondents standing for $8.39 \%$ were undecided; 17 respondents (11.89\%) disagree with the notion while 14 respondent standing for $9.79 \%$ strongly disagreed to this position.

Table 7 below exhibits response opinion as to whether the consistent application of behavior modification techniques such as positive reinforcement, negative reinforcement, punishment and extinction will facilitate repositioning of the banking firms for high profit status and competitive position.

Fifty-seven respondents representing 39.86\% strongly agreed on the opinion while 53 respondents standing for $37.06 \%$ also agreed. Sixteen respondents representing $11.19 \%$ disagreed with this thinking while 17 respondents standing for $11.89 \%$ strongly disagreed. There was no response option for undecided on this subject matter.

Hence, the agreement option constitutes $76.92 \%$ on this opinion, which is revealing that effective 
application of these behavior modification options will yield high profit to organizations and reposition their competitive positions.

Table 7

Respondents Perception That the Consistent Application of Behavior Modification Strategies Will Reposition the Banking Profit Status and Competitive Position

\begin{tabular}{lcc}
\hline Response Option & No of Respondents & $\%$ of Respondents \\
\hline Strongly Agree & 57 & $39.86 \%$ \\
Agree & 53 & $37.06 \%$ \\
Undecided & - & - \\
Disagree & 16 & $11.19 \%$ \\
Strongly Disagree & 17 & $11.89 \%$ \\
Total & 143 & 100 \\
\hline
\end{tabular}

Source: Field survey in 2014.

Table 8

Respondent Opinion Regarding the Claim That All the Behavior Modification Techniques Strategies are Equally Essential in Enhancing Profit Attainment

\begin{tabular}{lcc}
\hline Response Option & No of Respondents & \% of Respondents \\
\hline Strongly Agree & 65 & $45.45 \%$ \\
Agree & 62 & $43.36 \%$ \\
Undecided & - & - \\
Disagree & 10 & $6.99 \%$ \\
Strongly Disagree & 6 & $4.20 \%$ \\
Total & 143 & 100 \\
\hline
\end{tabular}

Source: Field survey in 2014.

For most of the respondents, behavior modification techniques/strategies are equally essential in enhancing profit attainment (see Table 8). Six-five respondents representing $45.45 \%$ of the respondents surveyed strongly agreed while 62 respondents $(43.36 \%)$ only agreed. No response option is for the undecided. Ten respondents standing for $6.99 \%$ disagreed while 6 respondents $(4.20 \%)$ strongly disagreed.

$\mathrm{H}_{1:}$ The effective application of behavior modification techniques has not significantly impacted the performance of the banking industry in Nigeria.

To test the null hypothesis, question/responses in Table 2, 3, 4, and 5 are used for the testing of the hypothesis as shown below.

$$
d f=(R-1) \times(C-1)=3
$$

Where, $R=4 ; C=1$;

level of significance $=0.07$;

$X_{0}^{2}$ under $0.07>7.815$ (critical value);

calculated value/chi-square $\left(X_{t}^{2}\right)=561.0581395$;

Decision: If the calculated or computed value of test statistics is less than or equal to Chi-square $\left(X_{0}^{2}\right)$ critical value, the null hypothesis is accepted.

However, if the computed value is greater or equal to chi-square critical value, the null hypothesis should 
be rejected, thus accepting the alternative hypothesis.

In this case, the calculated Chi-square $\left(X_{t}^{2}\right)$ value falls outside the rejection region.

Therefore, the null hypothesis is hereby rejected and the alternative hypothesis is accepted, i.e. $X_{0}^{2}<X_{t}^{2}$ (7. $815<561.0581395)$.

From the test it could be concluded that effective application of behavior modification techniques has significantly impacted the performance of the banking firms in Makurdi branches, Benue State, Nigeria.

$\mathrm{H}_{2}$ : Behavior modification techniques/strategies application has not enhanced the attainment of high profit status by the banking firms in Nigeria.

To test this null hypothesis, question/responses in Table 6 and 7 are used for the testing of the hypothesis as shown below (Table 9, 10, 11, and 12).

$$
d f=(R-1) \times(C-1)=2
$$

Where, $R=3 ; C=2$;

level of Significance $=0.07$;

$X_{0}^{2}$ under $0.07>7.815$ (critical value);

calculated value/chi-square $X_{t}^{2}=16.344758065$

Table 9

Contingency Coefficient Table on Effective Application on Behavior Modification Techniques for Test of Hypothesis 1

\begin{tabular}{lcc}
\hline $\begin{array}{l}\text { Descriptions } \\
\begin{array}{l}\text { Agreement } \\
\text { Category }\end{array}\end{array}$ & $\begin{array}{l}\text { Disagreement } \\
\text { Category }\end{array}$ & $\begin{array}{c}\text { Row Total } \\
\text { process for encouraging desirable workplace behavior and discouraging }\end{array}$ \\
$\begin{array}{l}\text { unwanted workplace. } \\
\begin{array}{l}\text { The banking industries adopt behavior modification techniques such as } \\
\text { positive reinforcement, negative reinforcement, punishment, and extinction. }\end{array}\end{array}$ & $28(33)$ & 143 \\
$\begin{array}{l}\text { Behavior modification techniques by your banking industries have enhanced } \\
\text { performance in a desired manner }\end{array}$ & $35(33)$ & 143 \\
$\begin{array}{l}\text { Behavior in organization can be modified only when managers identify the } \\
\text { critical observable and measurable work performance related behaviors to be } 100(110)\end{array}$ & $26(33)$ & 143 \\
$\begin{array}{l}\text { encouraged and discouraged } \\
\text { Column Totals }\end{array}$ & $43(33)$ & 143 \\
\hline
\end{tabular}

Table 10

Chi-square Table

\begin{tabular}{lrrrl}
\hline Cell & $O_{1}$ & $E_{1}$ & $O_{1}-E_{1}$ & \multicolumn{1}{c}{$\frac{\left(O_{1}-E_{1}\right)^{2}}{E_{1}}$} \\
\hline 1 & 115 & 110 & 5 & 0.2272727273 \\
2 & 28 & 33 & -5 & 0.7575757576 \\
3 & 108 & 35 & 73 & 161.4848485 \\
4 & 35 & 33 & 2 & 0.1212121212 \\
5 & 117 & 26 & 91 & 318.5 \\
6 & 26 & 33 & -7 & 1.484848485 \\
7 & 100 & 43 & 57 & 75.558133953 \\
8 & 43 & 33 & 10 & 3.03030303 \\
Total & 572 & 346 & 226 & 561.0581395 \\
\hline
\end{tabular}


Table 11

Contingency Coefficient Table on Effective Application on Behavior Modification Techniques for Test of Hypothesis 2

\begin{tabular}{|c|c|c|c|}
\hline Descriptions & $\begin{array}{l}\text { Agreement } \\
\text { Category }\end{array}$ & $\begin{array}{l}\text { Disagreement } \\
\text { Category }\end{array}$ & Row Total \\
\hline $\begin{array}{l}\text { Respondents opinion on whether High profit status is attained with the } \\
\text { application of Behavior modification techniques }\end{array}$ & $100(112)$ & $43(31)$ & 143 \\
\hline $\begin{array}{l}\text { Respondent opinion to whether the consistent application of behavior } \\
\text { modification techniques /strategies will reposition the banking profit status } \\
\text { and competitive position }\end{array}$ & $110(112)$ & $33(31)$ & 143 \\
\hline $\begin{array}{l}\text { All Behavior modification technique are equally essential in enhancing } \\
\text { profit attainment }\end{array}$ & $127(112)$ & $16(31)$ & 143 \\
\hline Column Total & 337 & 92 & 429 \\
\hline
\end{tabular}

Table 12

Chi-square Table

\begin{tabular}{lrrrl}
\hline Cell & $O_{1}$ & $\mathrm{E}_{1}$ & $O_{1}-\mathrm{E}_{1}$ & $\frac{\left(O_{1}-E_{1}\right)^{2}}{E_{1}}$ \\
\hline 1 & 100 & 112 & -12 & 1.285714286 \\
2 & 43 & 31 & 12 & 4.64516129 \\
3 & 110 & 112 & 2 & 0.0178571429 \\
4 & 31 & 2 & 0.1290322581 \\
5 & 127 & 112 & -16 & 2.0089285714 \\
6 & 16 & 31 & & 8.2580645161 \\
Total & 429 & 429 & & 16.344158065 \\
\hline
\end{tabular}

\section{Decision Criterion}

The null hypothesis is rejected if the computed value is greater than the critical (tabulated) value, otherwise, it is accepted.

As seen in the Chi-square table above (Table 12), the null hypothesis is rejected given that the computed value of the test statistics is greater than the critical value (i.e. $16.344758065>7.815$ ). Then the alternative hypothesis can be accepted and it can be concluded that high profit status is attained by the banking firms in Nigeria with the effective application of behavior modification techniques/strategies.

\section{Discussion}

Interesting, the study has produced startling discoveries as evident from the data presentation and analysis above.

First and foremost, it was found that effective application of behavior modification techniques and strategies has significantly impacted the performance of the banking firms, i.e. positive reinforcement, negative reinforcement, punishment, and extinction.

The implication of the above scenario is that the executive management of respective banking firms should create a department of ethical compliance and monitoring to checkmate from time to time to fish out erring staff and officers of the organization. This will require setting aside reasonable amount of monies to help this department by reinforcing positive behavior by staff that have detected financial frauds and making commensurate payment to officers in such a manner that they will not compromise. In order for the banking 
firms to attract desired behaviors, adequate and reasonable training is also required by the organizations human resources management department to facilitate efficiency, effectiveness, and productivity.

The above view agrees with those of Sev (2013) and Bartram (2014) who in their researches upheld that failure to observe the Central Bank of Nigeria ( $\mathrm{CBN})$ prudential guidelines and canon of lending/credit administration by bank chief/executive officers/managing directors will result in punishment and negative sanctions to erring staff.

The suspended CBN Governor, Mallam Sanusi Lamido Sanusi, in August 2009, over allegation of huge non-performing loans of respective banks namely Afri-Bank Plc, Union Bank Plc, and Intercontinental Bank Plc removed the chief executives and discovered and leveled criminal charges on them for violating the provisions of failed bank acts, craft laws of the Federation of Nigeria as well as other provisions of the banks and other financial institutions Act CAP B3, Laws of Nigeria in 2004. These former Managing Director/Chief Executive Officer are Mr. Francis Atuche (defunct AfriBank Plc), Okey Nwosu (defunct Finbank Plc), Mrs Cecilia Ibru (defunct Oceanic Bank Plc), Mr. Sebastine Adigwe (defunct Bank PHB of Nigeria Plc), Bartholomew Ebong (defunct Union Bank Nigeria Plc), and Dr. Erastus Akingbola (Intercontinental Bank Plc and Access Bank Plc). Of all the cases involving the former bank chief executive officers one ended with conviction, others are still in Federal High Court at preliminary stage (Bartram, 2014). The fact of the matter is that convicting and finding the guilty of these Managing Directors/Chief Executive Officers on just one charge are enough for them to receive commensurate punishments. This will discourage other Bank officers who had such negative intentions to withdraw and extinct from such acts.

In a similar vein, the former Nigeria Aviation Minister Mrs. Oduah Stella was relieved of her appointment as the minister for fraudulently awarding contract to a tune of 255 million for purchase of two BMW bullet-proof cars without observing the necessary due process as required by the Federal Government of Nigeria, Tender Board Process. Her behavior was modified through such a punishment by removing her from the position as minister. Other officers in love of defaulting tender Board due process procedure will extinct their negative work place behaviors.

It is rewarding to stress that any officer in an organization or staff of any Nigerian bank who is able to discover financial fraud will be reinforced positively with material or cash rewards.

Pertaining to profit attainment, it is rewarding to stress that with effective application of these strategies, high profit status will be derived. Desirable workplace behaviors will be upheld and undesired workplace behaviors will be discouraged. Profit according to Enikanselu and Oyende (2009) is regarded as income accruing to equity holders, in the same sense, as wages accruing to the labor, and rents accruing to the money lenders. It is an objective means of evaluating performance of the business.

With the application of these strategies, counterproductive behaviors, i.e. activities that damage the employees such as drug use and white-collar crimes, are eliminated. The most problematic counterproductive behaviors include employee theft, financial crimes, sabotage, employee coming to work under the influence of drugs and alcohol, whose performance is likely to be impaired (Noe \& Wright, 1996).

The implication for the above scenario is that for high performance and profit attainments, the banking firms need to apply outstanding strategies that will reengineer their present status. Total quality management techniques/strategies such as benchmarking for quality service delivery, methods of operations are needed. Outsourcing for expertise, skillful staff with core competencies is pertinent. Acquisition of Information 
Communication Technology (ICT) applications that will facilitate quality service delivery operations is important as well.

This agrees with the views of Yalokwu (2006) and Sev (1996) who acknowledged that quality application affects a firm in the following ways:

(1) Improved profitability. Improved quality results in improved profitability due to potential increase in market share as well as cost savings. The cost savings are as a result of lower rework and scrap costs, less wastages and lower warranty cost. The increase market share is as a result of higher volume in sales. Hence people will be willing to pay higher prices for better quality and hence it improves the profitability of the banking firm;

(2) Image and reputation of the company. Quality products not only produce the products but also the company. An organization must expect its reputation for quality good or bad to follow it. Based on quality, people develop certain perception about the firms' new products, employment practices, and their concern for consumers;

(3) Product liability. Through total quality management strategies, defective products which may cause damage or injury to the consumer are avoided;

(4) International implications. In the technological age and growth, constant global interaction, quality is an international concern. To meet global competition, a product must meet international quality standards and price expectations, given the importance of export trade as an economic factor for any country.

\section{Conclusions}

Organizations are formed to achieve certain set purposes. These purposes must be clearly stated and attainable. Exhibiting desired behavior by employees and discouraging undesirable behavior of employees will facilitate the attainment of desired goals and purpose of the organizations.

Management of organization can attained their purpose/goals by applying behavior modification techniques/reinforcement strategies such as positive reinforcement, negative reinforcement, punishment, and extinctions. Effective application using guidelines and rules in applying these strategies/techniques of behavior modification and reinforcement strategies is pertinent in all categories of organizations. This will facilitate the elimination of counterproductive behavior such as financial fraud, absenteeism, turnovers, employee theft, sabotage, employee coming to work under the influence of drugs and alcohol, faulting tender board due process for contracts award, and etc., with proper and effective compliance to guidelines in applying behavior modification techniques. There will be high productivity and performance status in the banking industry in Nigeria.

The research therefore recommends as follows.

Firstly, there should be strict adherence to rules and guidelines regarding the application of behavior modification techniques and strategies. This is to say that executive management needs to know the kinds of offences and circumstances that needed to be redressed with punishment, extinction, and negative reinforcement and should apply it within the spelt out criteria in order to have productive workforce organization.

Secondly, executive management should understand that punishment should be advanced against only undesirable behavior such as criminal offences sabotage, financial, fraud, theft, and etc., and it should be quick, short and take the form of withdrawal of rewards not physical pains. 
Thirdly, the executive management of the banking firms should understand that quality service delivery operations that will facilitate productive performance will be accomplished if officers that have detected and reported financial, fraudulent cases are rewarded with cash gifts, merits awards, and prizes. More to that, reinforcement of positive behavior will be effective if accomplished work targets set by management are positively rewarded with prizes, gifts to facilitate emulation by other members and citizenship behavior.

\section{References}

Bartram, N. (2014). Jurisdictional issues pose threat in trail of former banks chiefs. The Gurdian Newspaper, 14-15.

Bateman, T. S., \& Snell, S. A. (1999). Management: Building competitive advantage (4th ed.). Boston: Trwin McGraw-Hill Publishing.

Buchanan, D., \& Huczynski, A. (2004). Organizational behavior: An introductory text (5th ed.). London: Pearson Education Publishers.

Dyck, B., \& Neubert, M. J. (2009). Principles of management. Mason: South Western Cengage Learning.

Enikanselu, S. A., \& Oyende, A. I. (2009). Environment of business in Nigeria. Lagos: Ola Ventures Publishers.

Griffin, R. W. (1997). Management (5th ed.). Krishan Nagar: AITBS Publishers.

Hammer, W. C. (1977). Reinforcement theory and contingency management in organizational settings. New York: John Wiley and Sons, Inc.

Luthans, F. (2002). Organization behavior (9th ed.). Boston: Irwin McGraw-Hill Publishers.

Luthans, F., \& Kreitner, R. (1985). Organizational behavior modification and beyond: An operant and social learning approach. Glenview, IL: Scott, Foresman.

Luthans, F., Stajkovic, A., Luthans, B. C., \& Luthans, K. W. (1998). Applying behaviour management in Eastern Europe. European Management Journal, 16(4), 466-466.

Mcshane, S. L., \& Glinow, M. A. V. (2004). Organizational behavior. Boston: Irwin McGraw-Hill Publishers.

Noe, R., \& Wright, P. M. (1996). Management of organizations. Boston: Irwin McGraw-Hill.

Schermerhorn, J. R. Jr., Hunt, J. G., \& Osborn, R. N. (2005). Organizational behavior (9th ed.). New York: John Wiley and Sons, Inc..

Sev, J. T. (2006). Organizational behavior, concepts and applications (revised edition). Makurdi: Traces Publishing.

Sev, J. T. (2013). Management: Theory and practices. Makurdi: Saxon Publishers.

Skinner, W. (1981). Big hat, no cattle: Managing human resources. Harvard Business Review, 59(5), 106-114.

Stoner, J. A. F., Freeman, R. F., \& Gilbert, A. R. (2000). Management (6th ed.). New Delhi: Prentice Hall of India Private Limited.

Walters, C. C., \& Grusek, J. K. (1977). Punishment. San Francisco: Freeman Publishers.

Yalokwu, P. O. (2006). Fundamental of management (2nd ed.). Lagos: African centre of Management and Education.

Yamane, T. (1964). Statistics: An introductory analysis. New York: Harper and row Publishers.

\section{Appendix}

Here is a questionnaire on behaviour modification techniques/strategies.

As a tool for performance enhancement in the Nigeria banking industry, a survey of selected banks in Makurdi Metropolis, Benue State, Nigeria, West Africa is before you.

You have been chosen as one of the respondents in this study. You are therefore humbly requested to supply honest and sincere answers and responses to questions by tick $(\sqrt{ })$ as appropriately as you can in the boxes/spaces provided. There is no right or wrong answers.

Your identity is not needed at all and the information provided will be treated with utmost confidence and solely for academic purposes. 


\section{Questionnaires}

1. Behavior modification is a reinforcement process by which desired work place behaviors are encouraged and unwanted behavior discouraged using operant conditioning.

(a) SA (b) A (c) U (d) D (e) SD

2. Behavior modification techniques adopted by your banking firm include positive reinforcement, negative reinforcement, punishment and extinction?

(a) SA (b) A (c) U (d) D (e) SD

3. The application of behavior modification techniques by your banking firm have enhanced performance in a desired pattern.

(a) SA (b) A (c) U (d) D (e) SD

4. Behaviors in organization can be modified only when managers identify the critical, observable and measurable work performance-related behavior to be encouraged?

(a) SA (b) A (c) U (d) D (e) SD

5. Your banking organization has attained high profit status with the application of behavior modification strategies?

(a) SA (b) A (c) U (d) D (e) SD

6. Consistent application of these techniques will reposition the firms profit status and competitive position?

(a) SA (b) A (c) U (d) D (e) SD

7 All the four behavior modification techniques/strategies are equally essential in enhancing profit attainment?

(a) SA (b) A (c) U (d) D (e) SD

The objective of the study is to determine the impact of behavior modification techniques/strategies as a tool for performance enhancement in the Nigeria banking industry: A survey of selected banks in Makurdi metropolis, Benue State, Nigeria, West Africa. The data for this survey were obtained using primary and secondary sources. Five-point Likert scale rating questionnaire was used in obtaining the views and opinion of respondents (i.e. strongly agree -5 , agree -4 , undecided -3 , disagree -2 , and strongly disagree-1). Two hypotheses were formulated and tested with the aid of simple percentage and Pearson Chi-square test at $0.07 \%$ level of significance. The findings for the study revealed that effective application of behavior modification technique/strategies has significantly impacted the performance of the banking firms in Makurdi metropolis, Benue State, Nigeria. The second finding was that, high profit status is attained by the banking firms in Nigeria with the effective application of behavior recommending that there should be strict adherence to rules and guidelines regarding the application modification techniques/strategies. The study of behavior modification techniques/strategies bears in mind the offences, circumstances that needed reinforcement and behavior modification strategy for repositioning if the organizations are to have productive work force behavior. Secondly, executive management of the banking firm should understand that quality service delivery, operations that will facilitate productive performance will be accomplished if officers that have detected and reported financial fraudulent cases are rewarded with cash gifts, merit awards, and prizes. 